\title{
PENGGUNAAN BAHAN AJAR TEMATIK PEMBAGIAN UNTUK MENINGKATKAN HASIL BELAJAR DI KELAS IIA MI AHLIYAH II PALEMBANG
}

\author{
Luvi Antari \\ Program Studi Pendidikan Matematika FKIP UM Palembang \\ Email: luvi_fkipumpalembang@yahoo.com
}

\begin{abstract}
This study aims to look at improving student learning outcomes in the materials division using a thematic approach based teaching materials. This research is a classroom action research (Claassroom Action Research) with a research subject graders IIA MI Ahliyah 2 Palembang, the second semester of 2014/2015 the number of students 28 people, consisting of 14 male students and 14 female students. This study was conducted by two cycles following the model of a Class Action Research \& McTaggart Kemmis models which consists of four stages: planning, implementation, observation, and reflection. The process of collecting data by using observation and tests. Based on this research, the data obtained in the first cycle who scored $\geq 70$ there were 17 students with learning completeness percentage amounted to $60.71 \%$ of students had reached the indicators of success and the second cycle there are 23 students who reached a value $\geq 70$ on the percentage of students learning completeness by $82,14 \%$ had reached an indicator of success. With the student response rate reached $76.56 \%$ in the first cycle and the second cycle reaches $81.25 \%$. It can be concluded that learning by using a thematic approach based teaching materials division performed in this research was effective, because it can improve student learning outcomes in the distribution of matter in class IIA MI Ahliyah II Palembang
\end{abstract}

Keywords: a thematic approach, materials division

\section{PENDAHULUAN \\ Latar Belakang}

Sekolah Dasar (SD) merupakan lembaga formal pertama yang memiliki kewajiban untuk melaksanakan pembelajaran sesuai dengan kurikulum yang berlaku. Secara rentang formal pendidikan SD ditempuh dalam waktu enam tahun. Secara usia, anak-anak yang berada di sekolah dasar kisaran usianya adalah 6-13 tahun. Siswa kelas dua SD berada pada rentang usia dini, berada di kisaran usia 6-7 tahun. Pada usia tersebut seluruh aspek perkembangan kecerdasan, 
seperti IQ tumbuh berkembang sangat luar biasa, pada umumnya tingkat perkembangan masih melihat segala sesuatu sebagai satu keutuhan (holistic) serta mampu memahami hubungan antara konsep secara sederhana. Proses pembelajaran masih bergantung kepada objek - objek konkrit dan pengalaman yang dialami secara langsung (Depdiknas, 2006:3)

Dari hasil observasi dilapangan, ditemukan bahwa kesulitan penguasaan materi pembagian berdampak secara langsung terhadap perolehan hasil belajar siswa dalam tiga tahun terakhir. Rata-rata perolehan nilai pada materi pembagian pada tahun 2011/2012 adalah 61,17, tahun 2012/2013 adalah 59,8 dan tahun 2013/2014 adalah 55,41. Dengan KKM yang ditetapkan sebesar 70,0. Siswa yang mencapai KKM tahun 2011/2012 adalah 10 dari 23 siswa,tahun 2012/2013 adalah 12 dari 29 siswa dan tahun 2013/2014 adalah 12 dari 24 siswa. Berdasarkan data tersebut, dapat diketahui bahwa nilai pencapaian hasil belajar siswa materi pembagian tidak lebih dari $50 \%$. Hal tersebut dikarenakan kurangnya penggunaan pendekatan dan bahan ajar yang sesuai bagi pembelajaran materi pembagian.

Pembelajaran tematik adalah pembelajaran terpadu yang mengunakan tema sebagai permersatuan materi dalam beberapa mata pelajaran sekaligus dalam satu kali tatap muka (dalam Komariyah, 2013: 1).

Pembelajaran tematik merupakan salah satu bagian dari pembelajaran terpadu. Dalam pembelajaran terpadu,tema dapat digunakan untuk antar mata pelajaran dan inter mata pelajaran. Tujuan penggunaan tema adalah sebagai salah satu cara membawa situasi pembelajaran ke ranah yang lebih konkret bagi siswa. Penggunaan pembelajaran tematik juga dapat dikolaborasikan langsung dengan menggunakan bahan ajar yang disusun sendiri oleh guru sesuai dengan aspek tema yang lebih familiar bagi siswa. Tema yang dipilih disesuaikan dengan kondisi lingkungan dan budaya lokal yang dikenal oleh siswa. (Antari, 2010: 3)

Parameter dalam penelitian ini adalah hasi belajar. Hasil belajar merupakan hasil dari interaksi tindak belajar dan mengajar (Dimyati dan Mudjiono, 2009: 3). Sedang menurut Jihad dan Haris (2013: 14), hasil belajar adalah pencapaian bentuk perubahan perilaku yang cenderung menetap dari ranah kognitif, afektif dan psikomotorik dari proses belajar yang dilakukan dalam waktu tertentu.

Dalam penelitian ini, kurikulum yang digunakan adalah KTSP 2006, sesuai dengan kurikulum yang digunakan 
sekolah, bahan ajar pembelajaran tematik yang digunakan akan memakai Tema Jembatan Ampera Palembang dan Masjid Agung Palembang untuk antar mata pelajaran meliputi mata pelajaran Matematika, materi pembagian, Bahasa Indonesia, materi membaca wacana, IPS, materi jenis angkutan, Seni Budaya dan Keterampilan, materi menggambar berbagai jenis angkutan darat,laut dan udara.

Penelitian bertujuan untuk melihat penggunaan bahan ajar berbasis pendekatan tematik materi pembagian terhadap hasil belajar siswa kelas IIA MI Ahliyah Palembang.

\section{Tinjauan Pustaka}

\section{Pembelajaran Tematik}

Berdasarkan kutipan

Kunandar (2008: 340),

Pembelajaran tematik lebih menentukan pada keterlibatan siswa dalam proses belajar secara aktif dalam proses pembelajaran, sehingga siswa dapat memperoleh pengalaman langsung dan terlatih untuk menemukan sendiri berbagai pengetahuan yang dipelajarinya. Pembelajaran tematik lebih menekankan pada penerapan konsep belajar sambil melakukan sesuatu.

Hakikat pembelajaran tematik menurut Gagne dan Briggs (dalam Ahmadi, 2014: 55) mendefinisikan sebagai "Seting terintegrasi komponen strategi seperti; cara tertentuide-ide konten yang diurutkan, penggunaan ikhtisar dan ringkasan, penggunaan contoh, penggunaan praktik, dan penggunaan strategi yang berbeda untuk memotivasi siswa"

\section{Langkah-Langkah Pembelajaran Tematik}

Langkah - langkah pembelajaran tematik yaitu:

a. Merencanakan pembelajaran.

b. Mencanakan dampak pengiring (kerjasama, kemandirian, tanggung jawab, atau ketekunaan).

c. Melakukan proses pembelajaran.

d. Memberikan tugas sesuai kompetensi.

e. Melakukan layanan individu.

f. Memanfaatkan lingkungan sebagai media pembalajaran.

g. Memberi usulan pada hasil siswa.

h. Melakukan penilaian. (Antari,2010:10)

\section{Keunggulan dan Kelemahan Pembelajaran Tematik}

Pembelajaran tematik memiliki berbagai keunggulan, di antaranya:

a. Pengalaman dan kegiatan belajar sangat relevan dengan tingkat perkembangan dan kebutuhan anak usia sekolah dasar.

b. Kegiatan - kegiatan yang dipilih dalam pelaksanaan pembelajaran tematik ber-tolak dari minat dan kebutuhan siswa. 
c. Kegiatan belajar akan lebih bermakna dan berkesan bagi siswa, sehingga hasil belajar siswa dapat bertahan lebih lama.

d. Membantu pengembangan keterampilan berfikir siswa.

e. Menyajikan kegiatan belajar yang bersifat pragmatis sesuai dengan mengembang-kan keterampilan sosial siswa, seperti kerja sama siswa, toleransi, komunikasi dan tanggap terhadap gagasan orang lain.

\section{Kelemahan}

Tematik

Pembelajaran tematik memiliki berbagai kelemahan, di antaranya:

a. Guru dituntut untuk memiliki keterampilan yang tinggi.

b. Tidak setiap guru mampu mengintergrasikan kurikulum dengan konsep - konsep yang ada dalam mata pelajaran secara tepat. (Antari,2010:11)

\section{METODE PENELITIAN}

Penelitian ini merupakan Penelitian Tindakan Kelas (PTK) yang menggunakan pendekatan kualitatif. Penelitian ini disebut PTK karena dilakukan untuk memecahkan masalah pembelajaran di kelas. Menurut Kunandar (2011:45) penelitian tindakan kelas adalah peelitian tindakan yang dilakukan dengan tujuan memperbaiki mutu praktik pembelajaran di sekolah.
Penelitian ini dilakukan di Kelas IIA MI Ahliyah Palembang pada semester genap tahun pelajaran 2014/2015. Subjek penelitian berjumlah 28 orang yang terdiri atas 14 siswa lakilaki dan 14 siswa perempuan. Penelitian ini yang bertujuan untuk melihat peningkatan hasil belajar siswa materi pembagian yang diajarkan dengan menggunakan bahan ajar berbasis pendekatan tematik.

Sumber data pada penelitian ini meliputi instrumen penelitian yang berupa seperangkat alat pembelajaran, berupa bahan ajar matematika yang dikembangkan dengan berbasis pendekatan tematik, sedangkan prosedur pengumpulan data meliputi data hasil tes yag diberikan setelah akhir pembelajaran dan data hasil observasi yang diperoleh dari hasil pengamatan.

Data hasil tes dan observasi akan dianalisis dengan menggunakan tehnik analisis data kualitatif, yang salah satu modelnya adalah tehnik analisis interaktif yang dikembangnkan oleh Miles dan Huberman (Kunandar, 2008: 101-103) yaitu dengan cara reduksi data,beberan data dan penarikan kesimpulan.

\section{HASIL PENELITIAN DAN PEMBAHASAN}

Penelitian ini dilakukan sebanyak dua siklus mengikuti model Penelitian Tindakan Kelas dari model Kemmis \& McTaggart 
yang terdiri dari empat tahapan yaitu: perencanaan, pelaksanan, observasi, dan refleksi. (Kunandar, 2011: 96)

\section{Paparan Data Siklus I}

Pelaksanaan kegiatan pada Siklus I meliputi tahapan perencanaan, implementasi tindakan, observasi dan refleksi.

a. Tahap Perencanaan

Meliputi persiapan perangkat pembelajaran, yaitu RPP, Silabus, Bahan Ajar dan alat ukur berupa tes.

b. Tahap Implementasi Tindakan Siklus I dilakukan sebanyak dua kali pertemuan. Pertemuan pertama pada 10 April 2015 dan kedua pada 13 April 2015. Pada Siklus I pertemuan pertama, diberikan bahan ajar tematik yang bertemakan Jembatan Ampera Palembang, didalam bahan ajar tersebut memuat materi pelajaran secara ringkas, meliputi 4 mata pelajaran yang tergabung dalam tema tersebut.Peneliti melakukan penelitian dengan didampingi teman sejawat yang berlaku sebagai pengamat. Pertemuan kedua, dilakukan tes yang berkaitan dengan materi yang telah diajarkan. Hasil tes pada siklus I diperoleh data bahwa dari 28 siswa yang mengikuti tes, 17 siswa atau $60,71 \%$ dinyatakan tuntas dan 11 siswa atau $39,29 \%$ belum tuntas belajar. Hal ini disebabkan masih banyak siswa yang nialinya belum mencapai KKM.

c. Tahap observasi

Observasi dilakukan oleh dua orang teman sejawat untuk mengamati kegiatan pembelajaran yang berlangsung, baik kegiatan siswa maupun kegiatan guru. Analisis data observasi menggunakan persentase. Skor yang diperoleh dari masing,asing indikator dan hasilnya disebut jumlah skor. Berdasarkan hasil observasi pengamat, persentase rata-rata proses kegiatan pembelajaarn terlaksana $76,56 \%$ untuk kegiatan peneliti sebagai guru, dan $73,44 \%$ untuk kegiatan siswa, yang artinya taraf keberhasilannya telah terpenuhi.

d. Tahap Refleksi Siklus I

Pada siklus I, pencapaian persentase ketuntasan bagi siswa belum mencapai harapan yaitu $80 \%$, dari hasil temuan di siklus I ada beberapa hal yang membuat penggunaan bahan ajar tematik materi pembagian belum sesuai harapan, antara lain siswa masih kesulitan memilah materi yang dikaitkan secara bersamaan dalam satu tema, ada beberapa siswa yang melewati materi matematika dan langsung ke pelajaran lain yang disukainya seperti SBK dan alokasi waktu yang sedikit terburu-buru. Selain itu situasi kelas yang masih sulit 
dikendalikan mengakibatkan waktu pembelajaran menjadi berlebih.

\section{Paparan Data Siklus II}

Pelaksanaan kegiatan pada Siklus II meliputi tahapan perencanaan, implementasi tindakan, observasi dan refleksi.

a. Tahap Perencanaan

Perencanaan siklus II dilakukan dengan melihat hasil refleksi pada siklus I. Meliputi perbaikan persiapan perangkat pembelajaran, yaitu RPP disesuaiakan dengan temuan pada siklus I, Silabus, Bahan Ajar dan alat ukur berupa tes.

b. Tahap Implementasi Tindakan Siklus I dilakukan sebanyak dua kali pertemuan. Pertemuan pertama pada 17 April 2015 dan kedua pada 20 April 2015. Pada Siklus II pertemuan pertama, diberikan bahan ajar tematik yang bertemakan Masjid Agung Palembang, didalam bahan ajar tersebut memuat materi pelajaran secara ringkas, meliputi 4 mata pelajaran yang tergabung dalam tema tersebut.Peneliti melakukan penelitian dengan didampingi teman sejawat yang berlaku sebagai pengamat. Pertemuan kedua, dilakukan tes yang berkaitan dengan materi yang telah diajarkan. Hasil tes pada siklus I diperoleh data bahwa dari 28 siswa yang mengikuti tes, 23 siswa atau $82,14 \%$ dinyatakan tuntas dan
5 siswa atau $17,86 \%$ belum tuntas belajar.Hal ini disebabkan masih banyak siswa yang nialinya belum mencapai KKM.

c. Tahap observasi

Observasi dilakukan oleh dua orang teman sejawat untuk mengamati kegiatan pembelajaran yang berlangsung, baik kegiatan siswa maupun kegiatan guru. Analisis data observasi menggunakan persentase. Skor yang diperoleh dari masing,asing indikator dan hasilnya disebut jumlah skor. Berdasarkan hasil observasi pengamat, persentase rata-rata proses kegiatan pembelajaran terlaksana $84,38 \%$, untuk kegiatan peneliti sebagai guru dan $81,25 \%$ untuk kegiatan siswa,yang artinya taraf keberhasilannya telah terpenuhi.

d. Tahap Refleksi Siklus I

Pada siklus II, pencapaian persentase ketuntasan bagi siswa mencapai harapan yaitu $82,14 \%$, dari hasil temuan di siklus II masih ada sedikit kendala antara lain masih adanya siswa yang tidak runut dalam mengerjakan bahan ajar.Waktu yang digunakan sudah lebih efisien, tidak terlalu berlebih, namun secara keseluruhan, Siklus II berhasil dan tidak perlu untuk dilanjutkan ke siklus berikutnya. 


\section{KESIMPULAN DAN SARAN Kesimpulan}

Berdasarkan hasil penelitian dan pembahasan di atas, maka dapat diambil kesimpulan bahwa:

a. Penggunaan bahan ajar matematika tematik materi pembagian dapat meningkatkan hasil belajar siswa kelas IIA MI Ahliyah II Palembang. Hal ini dapat dilihat dari persentase ketuntasan belajar siswa pada siklus I mencapai $60,71 \%$ dan siklus II $82,14 \%$.

b. Berdasarkan pengamatan yang dilakukan dua pengamat terhadap kegiatan belajar mengajar yang dilakukan peneliti, menunjukkan bahwa proses pembelajaran berjalan baik, dilihat dari persentase pengamatan yang mencapai $76,56 \%$ pada siklus I dan siklus II mencapai $81,25 \%$

\section{Saran}

Dari penelitian tindakan kelas dengan menggunakan bahan ajar berbasis pendekatan tematik pembagian di kelas II Sekolah Dasar, diperoleh temuan yang dapat menjadi dasar perbaikan dalam pelaksanaan pembelajaran tersebut.

Berikut saran yang sekiranya dapat digunakan oleh peneliti lain yang tertarik untuk menggunakan pembelajaran ini penggunaan pembelajaran tematik sangat tepat digunakan di sekolah dasar. Pembelajaran ini mampu membuat situasi belajar lebih aktif serta mampu menggali rasa ingin tahu pada siswa,tetapi pengendalian situasi kelas juga diperlukan supaya hasil yang lebih maksimal dan penggunaan waktu akan lebih efektif.

\section{DAFTAR PUSTAKA}

Ahmadi, Iif Khoiru. 2014. Pengembangan \& Model Pembelajaran Tematik Integratif. Jakarta: Prestasi Pustaka Publisher Depdiknas, 2006. Kurikulum Tingkat Satuan SD dan MI. Jakarta: Bumi Aksara.

Dimyati dan Mudjiono. 2009. Belajar dan Pembelajaran. Jakarta: Rineka Cipta.

Jihad, A., dan Haris, A. 2013. Evaluasi Pembelajaran. Jakarta: Multipresindo.

Kunandar. 2008. Guru Profesional: Implementasi Kurikulum Tingkat Satuan Pendidikan (KTSP) dan Sukses dalam Sertifikasi Guru. Bandung: Raja Granfindo Persada.

Kunandar. 2011. Penelitian Tindakan Kelas. Jakarta: Raja Grafindo Persada

Antari, L. 2010. Pengembangan Bahan Ajar Matematika Tematik Materi Pembagian di kelas II SD Islam Az 
ISSN 2442-5419 Vol. 4, No. 2 (2015) 22-29

Zahrah Palembang. Tesis, Palembang

Komariyah, N. 2013. Perbandingan Hasil Belajar Matenatika Siswa Antara Model Pembelajaran Tematik dengan Model Pembelajaran Langsung (Directive Learning) Pada Mata Materi Keliling Persegi dan Persegi Panjang di Kelas III SD 163 Palembang. Skripsi Palembang. 